\title{
Genetic diversity and relationship in American and African oil palm as revealed by RFLP and AFLP molecular markers ${ }^{(1)}$
}

\author{
Edson Barcelos $^{(2)}$, Philippe Amblard(3), Julien Berthaud( ${ }^{(4)}$ and Marc Seguin ${ }^{(3)}$
}

\begin{abstract}
The objective of this work was to evaluate the genetic diversity, its organization and the genetic relationships within oil palm (Elaeis oleifera (Kunth) Cortés, from America, and E. guineensis (Jacq.), from Africa) germplasm using Restriction Fragment Length Polymorphism (RFLP) and Amplified Fragment Length Polymorphism (AFLP). In complement to a previous RFLP study on 241 E. oleifera accessions, 38 E. guineensis accessions were analyzed using the same $37 \mathrm{cDNA}$ probes. These accessions covered a large part of the geographical distribution areas of these species in America and Africa. In addition, AFLP analysis was performed on a sub-set of 40 accessions of E. oleifera and 22 of $E$. guineensis using three pairs of enzyme/primer combinations. Data were subjected to Factorial Analysis of Correspondence (FAC) and cluster analysis, with parameters of genetic diversity being also studied. Results appeared congruent between RFLP and AFLP. In the E. oleifera, AFLP confirmed the strong structure of genetic diversity revealed by RFLP, according to geographical origin of the studied material, with the identification of the same four distinct genetic groups: Brazil, French Guyana/Surinam, Peru, north of Colombia/Central America. Both markers revealed that genetic divergence between the two species is of the same magnitude as that among provenances of $E$. oleifera. This finding is in discrepancy with the supposed early tertiary separation of the two species.
\end{abstract}

Index terms: Elaeis oleifera, Elaeis guineensis, population genetics, palm species, genetic resources, molecular chacterization.

\section{Diversidade e relação genética entre o dendê americano e o africano revelada por marcadores moleculares do tipo RFLP e AFLP}

\begin{abstract}
Resumo - O objetivo deste trabalho foi avaliar a diversidade genética, sua organização e a relação genética no germoplasma de dendê (Elaeis oleifera (Kunth) Cortés, de origem americana, e E. guineensis (Jacq.), africana), pelas técnicas de Polimorfismo de Comprimento de Fragmentos de Restrição (Restriction Fragment Length Polymorphism - RFLP) e Polimorfismo de Comprimento de Fragmentos Amplificados (Amplified Fragment Length Polymorphism - AFLP). Em complemento a um estudo prévio de RFLP em 241 acessos de E. oleifera, 38 acessos de E. guineensis foram analisados usando as mesmas 37 sondas de cDNA. Os acessos estudados cobrem uma grande parte da área de distribuição geográfica destas duas espécies nos continentes Americano e Africano, respectivamente. Além disso, análises com marcadores AFLP foram realizadas em uma subamostra com 40 acessos de E. oleifera e 22 de E. guineensis, empregando três combinações de pares enzima/primer. Os dados foram submetidos à análise fatorial de correspondência (AFC) e análise de cluster, sendo também estimados parâmetros de diversidade genética. Os resultados obtidos apresentaram grande coerência entre as duas técnicas utilizadas, RFLP e AFLP. Na espécie E. oleifera, a técnica AFLP confirmou a forte estruturação da diversidade genética revelada pela técnica de RFLP, de acordo com a origem geográfica do material estudado e com a identificação dos mesmos quatro grupos genéticos distintos: Brasil, Guiana Francesa/Suriname, Peru e norte da Colômbia/ América Central. Entretanto, ambos os marcadores revelaram que a divergência entre as duas espécies é da mesma magnitude da divergência dentro da espécie americana. Este resultado está em discrepância com uma suposta separação das duas espécies durante a era terciária.
\end{abstract}

Termos para indexação: Elaeis oleifera, Elaeis guineensis, genética de população, palmeiras, recursos genéticos, caracterização molecular.

(1) Accepted for publication on September 25, 2001.

Part of the Ph.D. thesis presented by the first author to the University of Montpellier III, France.

(2) Embrapa-Centro de Pesquisa Agroflorestal da Amazônia Ocidental, Caixa Postal 319, CEP 69011-970 Manaus, AM. E-mail: barcelos@cpaa.embrapa.br
${ }^{(3)}$ Centre de Coopération Internationale en Recherche Agronomique pour le Développement, Boite Postale 3053, Cedex 1, 34032 Montpellier, France. E-mail: amblard@cirad.fr, seguin@cirad.fr

(4) Institut de Recherche pour le Développement, Boite Postale 5045, Cedex 1, 34032 Montpellier, France. E-mail: berthaud@ird.fr 


\section{Introduction}

Oil palm (Elaeis guineensis) is a crop widely cultivated in the humid tropics and represents one of the most important sources of vegetable oil. The history of oil palm breeding points to a narrow genetic base in the cultivated varieties. Presently, oil palm breeders are demanding for agronomic traits, such as disease resistance, oil fluidity, low growth rate and broad ecological adaptations, for which restricted genetic variability has been found on E. guineensis germplasm (Hartley, 1988; Simmonds, 1993).

To broaden the oil palm genetic base, extensive germplasm collections were made in its natural range in Africa (E. guineensis) and in tropical America (E. oleifera) (Rajanaidu, 1994).

The wild American species E. oleifera is seen as a promising genetic resource for oil palm breeding programs, for improvement of tolerance to some lethal abnormalities in Latin America; oil quality improvement; slow trunk growth elsewhere. Despite being geographically isolated, these two species are cross-compatible and fertile hybrids can be easily obtained (Hardon \& Tan, 1969; Amblard et al., 1995). The characterization of these genetic resources constitutes the first step to their effective utilization (Simmonds, 1993).

Molecular markers are supposedly free of environmental influence and readily detected at any stage in any part of the plant, through direct genome analysis. Therefore, markers provide an efficient method for genetic resources characterization, through which genetic diversity and organization at different levels can be assessed (Karp \& Edwards, 1997; Lanaud \& Lebot, 1997). RFLP has been broadly and successfully used to characterize genetic resources including some tropical perennial crops (Besse et al., 1994; N'goran et al., 1994; Jack et al., 1995; Lebrun et al., 1995; Luo \& Boutry, 1995; Lerceteau et al., 1997). However, this technique requires a relatively large quantity of good quality DNA and the best results are obtained using radioisotopes, which makes RFLP technically and ecologically sensitive. It is also labor and cost intensive for the characterization of a large number of accessions.

The new PCR-based technique for DNA fingerprinting, Amplified Fragment Length Polymorphism (AFLP), has proven to be a reliable genetic molecular marker. AFLPs reveal significant levels of DNA polymorphism by rapidly screening many independent genetic loci in a single assay. Its simple handling allows detailed genetic studies in a large number of genotypes with relatively low effort compared to other techniques (Vos et al., 1995; Hill et al., 1996; Powell et al., 1996; Sharma et al., 1996; Paul et al., 1997).

The efficiency of RFLP for genetic diversity studies is well known, and the use of AFLP is more recent. Few studies (Marsan et al., 1998) compared both techniques to estimate genetic diversity and genetic structure within relevant sample size.

A RFLP analysis on 241 accessions of $E$. oleifera, was previously reported by Barcelos et al. (2000), using 37 cDNA. These analyses revealed a strong geographical structure, with four distinct genetic groups: Brazil, French Guyana/Suriname, Peru and north of Colombia/Central America. For this group structure, the RFLP analysis (co-dominant markers) revealed that $74 \%$ of the genetic variability were due to inter-groups divergence, while considering only Brazilian accessions, structured in 32 populations, only $35 \%$ of variability were due to inter-populations divergence.

This study aimed to characterize genetic diversity and relationships between perennial tropical species, E. oleifera (Kunth) Cortés, from America, and E. guineensis (Jacq), from Africa, through RFLP and AFLP molecular marker techniques.

\section{Material and Methods}

\section{Genetic material and DNA extraction}

The RFLP analysis was performed on 38 E. guineensis accessions in addition to the 241 E. oleifera accessions previously analyzed by Barcelos et al. (2000) (Table 1). The AFLP analysis was performed on a subset of 40 E. oleifera and 22 E. guineensis accessions (Table 1). These samples cover a broad area of the natural distribution area of these species. 
For E. oleifera, each accession corresponded to a tree growing at an experimental station, raised from an open pollinated seed collected directly from a tree in a natural population (Rajanaidu, 1994). For E. guineensis, the accessions were equivalent to the American species, with some origins (La Mé, Yangambi, Deli, Angola, Cameroon), being full-sib or half-sib descendants obtained from a tree growing in an experimental station and representing its original population in Africa.

Leaf samples of each accession were harvested from plants growing at Oil Palm Research Stations in Brazil (Embrapa/Manaus) and Côte d'Ivoire (Idefor/Abidjan). Total DNA was extracted from $3 \mathrm{~g}$ of fresh or $1 \mathrm{~g}$ of lyophilized leaves, using a CTAB protocol.

\section{RFLP and AFLPTM procedures}

The RFLP protocols and probes used were exactly the same as previously described by Barcelos et al. (2000). Identity of the bands or alleles between the two species was assessed by the presence of E. oleifera samples as control in E. guineensis blots.

The AFLP ${ }^{\mathrm{TM}}$ analyses were performed by using procedures described by Vos et al. (1995). Three pairs of primers were used: $E c o \mathrm{RI}_{\mathrm{AGA}} / M s e \mathrm{I}_{\mathrm{CAC}}, E c o R \mathrm{I}_{\mathrm{AGA}} /$ $M s e \mathrm{I}_{\mathrm{CAG}}$ and $E c o \mathrm{RI}_{\mathrm{AAC}} / M s e \mathrm{I}_{\mathrm{CAC}}$. Fragments were automatically detected on the gel-scans produced from

Table 1. Accessions of Elaeis oleifera and E. guineensis used in the RFLP and AFLP genetic diversity study.

\begin{tabular}{|c|c|c|c|}
\hline \multirow[t]{2}{*}{$\begin{array}{l}\text { Country of } \\
\text { origin }\end{array}$} & \multirow[t]{2}{*}{$\begin{array}{l}\text { Number of } \\
\text { populations }\end{array}$} & \multicolumn{2}{|c|}{$\begin{array}{l}\text { Number of } \\
\text { accessions }\end{array}$} \\
\hline & & RFLP & AFLP \\
\hline & \multicolumn{3}{|c|}{ E. oleifera } \\
\hline Brazil & 59 & 177 & 24 \\
\hline Colombia & 5 & 16 & 4 \\
\hline Costa Rica & 3 & 9 & 2 \\
\hline French Guyana & 2 & 10 & 2 \\
\hline Nicaragua & 1 & 4 & 2 \\
\hline Panama & 8 & 14 & 2 \\
\hline Peru & 1 & 5 & 2 \\
\hline Surinam & 2 & 6 & 2 \\
\hline \multirow[t]{2}{*}{ Total } & 81 & 241 & 40 \\
\hline & \multicolumn{3}{|c|}{ E. guineensis } \\
\hline Deli / Bogor ${ }^{(1)}$ & 4 & 5 & 3 \\
\hline Côte d'Ivoire ${ }^{(2)}$ & 2 & 6 & 3 \\
\hline Congo / Zaire ${ }^{(3)}$ & 2 & 8 & 3 \\
\hline Nigeria & 5 & 6 & 4 \\
\hline Angola & 2 & 5 & 3 \\
\hline Benin & 1 & 1 & 1 \\
\hline Cameroon & 3 & 3 & 3 \\
\hline Brazil $^{(4)}$ & 4 & 4 & 2 \\
\hline Total & 23 & 38 & 22 \\
\hline
\end{tabular}

(1)Introduced from Africa into Indonesia in 1848. (2)La Mé and Yocoboué origins. ${ }^{(3)}$ Yangambi/Sibiti origins. ${ }^{(4)}$ Introduced from Africa into Brazil (State of Bahia) by slaves in $17^{\text {th }}$ century. digitalized images by a Molecular Dynamics Laser Phosphoimager (Linkage Genetics).

\section{Data analysis}

The genetic variability in E. oleifera and E. guineensis germplasm was studied by using RFLP and AFLP molecular markers. The data were obtained with a set of 37 nuclear cDNA anonymous probes for the RFLP analysis, and three pairs of primer/enzyme combinations for the AFLP analysis. All markers were scored as band of dominant markers.

The RFLP fragments were scored as dominant binary markers, by presence (1) or absence (0), for all 37 pairs of probe/enzyme combinations retained for this study. The AFLP fragments were also coded in the same way.

The Factorial Analysis of Correspondences, FAC (Benzecri, 1973), was performed separately on RFLP and AFLP data, using algorithms of the ADDAD software package (Lebeaux, 1985) on disjunctive matrix data; i.e., each variable band was split in two new variables: $\mathrm{V} 1=$ presence and $\mathrm{V} 0=$ absence of the band. Application of FAC algorithm on such disjunctive matrix is also called Multiple Correspondence Analysis.

The molecular genetic diversity was estimated at species level and according to the group structure revealed by FAC analysis, through the classical parameters of population genetics, like percentage of polymorphic fragments and Nei's genetic diversity index (Nei, 1973). Cluster analyses were performed using Nei's unbiased genetic distance (Nei, 1978) for accessions grouped according to geographical origin.

The gene diversity (Nei, 1973) level within group was analyzed, considering five groups (geographical origins of accessions: Brazil, Peru, French Guyana, Surinam and Central America) and Dice similarity index (Nei \& Li, 1979) for inter-accessions genetic distance estimation, when accession number was small. Dendrograms were used to visualize possible genetic relationships among restricted groups or accessions, by applying the ultrametric UPGMA method using Popgene, NTSYS and ABCD software packages.

\section{Results and Discussion}

\section{RFLP}

The 37 selected cDNA probes applied over 241 accessions of E. oleifera and 38 accessions of E. guineensis produced 278 RFLP polymorphic fragments, coded as dominant markers and retained for FAC statistical analysis. 
For the total of 278 polymorphic bands, detected by 37 probes, 248 RFLP were present in E. oleifera accessions and 170 in E. guineensis. Of these fragments, 108 were specific to $E$. oleifera, while only 30 were specific to E. guineensis, and 140 were common to both species. Within the American species, 33 fragments were specific to accessions from Brazil, while only between three to eight were specific to other American origins (Table 2).

For all 278 RFLP polymorphic markers, the percentage of polymorphism was $46 \%$ in E. guineensis and $86 \%$ in E. oleifera. The Brazilian accessions had $65 \%$ of polymorphic markers, while other groups had between $8 \%$ to $15 \%$ polymorphic markers (Table 2).

Nei's (1973) genetic diversity was $\mathrm{H}=0.225$ in the American and $\mathrm{H}=0.135$ in the African species (Table 2). The latter is of the same order of magnitude found within the Brazilian origins $(H=0.157)$. Similar results were obtained for the RFLP allelic data. In this analysis, the level of diversity in the African species was $\mathrm{H}=0.297$ while $\mathrm{H}=0.245$ for the Brazilian population (Barcelos et al., 2000).

The first two axes of the FAC represented $35 \%$ of the total variation (Figure 1). On this plane, the two species separated within four geographical distinct groups for the E. oleifera: Brazil, Surinam/French Guyana, north of Colombia/Central America and Peru. In this FAC, the Brazilian group is clearly separated from all others by the $1^{\text {st }}$ axis, representing $21 \%$ of total variation.

The genetic distances (Nei, 1978) among these groups based on RFLP bands (Table 3 ) revealed divergence among American species (Mean $=0.330$, varying from 0.114 to 0.425 ), with accessions from French Guyana and Surinam being genetically close as indicated by FAC analysis. The divergence between the two species (Mean Nei' $\mathrm{S}_{\mathrm{UGD}}=0.289$, varying from 0.276 to 0.321 ), appeared to be smaller than the divergence within the American species ( 0.140 to 0.425 ). The cluster analysis (Figure 2) showed a close relationship between the French Guyana and Surinam accessions, while indicating that the diversity present in African species are encompassed by the diversity presented by the American.

The RFLP data from the 38 accessions of E. guineensis were separately subjected to a FAC analysis. The $1^{\text {st }}$ plane, representing $24 \%$ of the overall variability, presented three groups formed by accessions representing La Mé/Côte d'Ivoire and Yangambi/Zaire origins, and a third group with Deli and other African origins (Figure 3).

\section{Genetic information revealed by AFLP}

The AFLP pairs of primer/enzyme combinations used to analyze 40 accessions of E. oleifera and 22 accessions of $E$. guineensis (Table 1) revealed a total of 169 polymorphic fragments. Each primer pair revealed from 46 to 63 polymorphic loci. Fragments presenting the same size in different genotypes were considered to be identical.

Seventy fragments (40.7\% of 172 detected AFLPs) were common to both species; 96 fragments $(55.8 \%)$ were specific to E. oleifera and only three $(1.7 \%)$ were specific to E. guineensis (Table 4). Regardless of the differences in sample size, E. oleifera presented a much higher number of polymorphic markers (95\%) than E. guineensis (38\%).

AFLP polymorphic products were scored for presence or absence, and were used in factorial analysis of correspondences. The first two axes of

Table 2. Genetic diversity estimated by 278 nuclear RFLP bands revealed by 37 cDNA probes on 241 accessions of E. oleifera and 38 accessions of E. guineensis.

\begin{tabular}{|c|c|c|c|c|c|c|}
\hline \multirow[t]{2}{*}{ Species } & \multirow[t]{2}{*}{ Group } & \multirow{2}{*}{$\begin{array}{l}\text { Sample } \\
\text { size }\end{array}$} & \multirow{2}{*}{$\begin{array}{c}\text { Polymorphic } \\
\text { loci }(\%)\end{array}$} & \multicolumn{2}{|c|}{ Number of fragments } & \multirow{2}{*}{$\begin{array}{c}\text { Gene } \\
\text { diversity }^{(1}\end{array}$} \\
\hline & & & & Total & Specific & \\
\hline \multirow[t]{6}{*}{ E. oleifera } & Brazil & 177 & 65 & 96 & 33 & 0.157 \\
\hline & French Guyana & 10 & 11 & 82 & 4 & 0.042 \\
\hline & Central America & 43 & 15 & 92 & 6 & 0.047 \\
\hline & Peru & 5 & 10 & 90 & 8 & 0.042 \\
\hline & Surinam & 6 & 8 & 89 & 3 & 0.035 \\
\hline & Total & 241 & 86 & 248 & 108 & 0.225 \\
\hline E. guineensis & Africa & 38 & 46 & 170 & 30 & 0.135 \\
\hline
\end{tabular}

(1) Nei (1973). 
the FAC represented $38 \%$ of the total variation (Figure 4). On this plane, the two Elaeis species were clearly separated. Also, a geographical structure within the American species (E. oleifera) is evident. Four genetic groups can be distinguished: Brazil, Surinam/French Guyana, north of Colombia/Central America and Peru. This result was similar to the other based on RFLP.

FAC performed on the RFLP data with the same E. oleifera and E. guineensis accessions analyzed by AFLP technique, showed similar results. However, a lower within-group variability was detected.

Cluster analysis based on Dice similarity index (Nei \& Li, 1979) on AFLP data set and considering

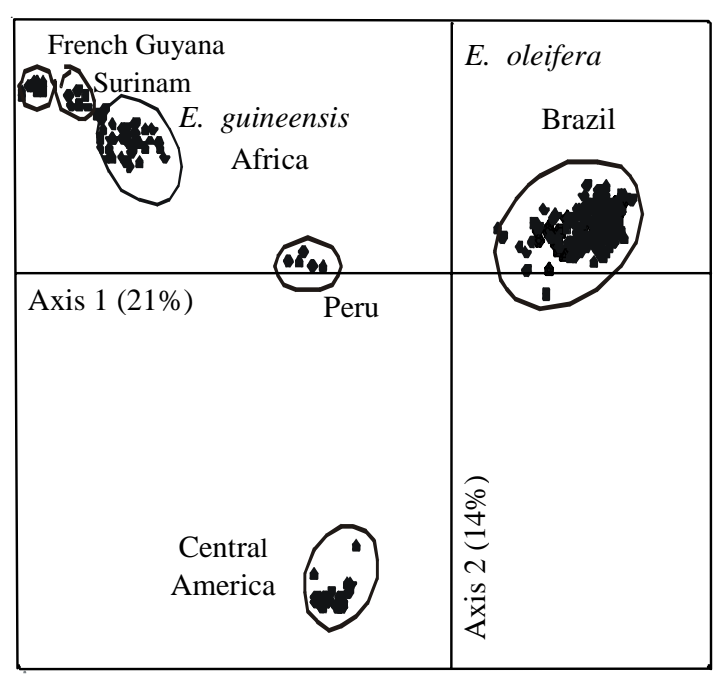

Figure 1. Factorial Analysis of Correspondences of 278 nuclear RFLP bands on 241 E. oleifera and 38 E. guineensis accessions. First plane (Axes 1-2) representing 35\% of overall variability. each accession independently (Figure 5) showed that the African accessions are distinct from the American groups. The inter-species genetic diversity was higher than within E. oleifera, with a mean Dice genetic distance of 0.753 (varying from 0.720 to 0.790 ). This analysis showed a slight structuring within E. guineensis, while there was a clear separation in the Brazilian accessions of E. oleifera in the group following the network of rivers in the Amazon.

These results revealed a different relationship between the two species, when compared with the cluster analysis with the same data set considering the accessions grouped by geographical origins (Table 3) or with RFLP results (Figure 2).

\section{Genetic diversity structures}

FAC performed separately on RFLP (Figure 1) and on AFLP data (Figure 4) consistently showed five distinct groups: one made up of E. guineensis species, and four groups of E. oleifera: Surinam/ French Guyana, Peru, north of Colombia/Central America and Brazil. The RFLP dominant data analysis revealed some divergence between French Guyana and Surinam accessions.

The RFLP cluster analysis performed on the whole data set placed the African source among E. oleifera groups, between the French Guyana/Surinam and all other American (Figure 2). This structure can be interpreted as the consequence of a great percentage of markers being common to both species (Table 2).

The divergence among groups from north of Colombia/Central America, Peru and French Guyana/ Surinam origins ( 0.256 to 0.408$)$ presented greater than the divergence between species ( 0.276 to 0.321 ).

Table 3. Genetic divergence between groups revealed by Nei's unbiased genetic distance (Nei, 1978) estimated with 248 nuclear RFLP bands revealed by 37 cDNA probes over 241 accessions of E. oleifera and 38 accessions of E. guineensis (below diagonal) and with 169 AFLP markers revealed by three primer/enzyme combinations over 40 accessions of E. oleifera and 22 accessions of E. guineensis (above diagonal).

\begin{tabular}{llcccccc}
\hline Species & Group & Brazil & Fr. Guyana & C. America & Peru & Surinam & Africa \\
\hline E. oleifera & Brazil & - & 0.601 & 0.301 & 0.248 & 0.562 & 0.411 \\
& French Guyana & 0.404 & - & 0.678 & 0.528 & 0.090 & 0.499 \\
& Central America & 0.256 & 0.425 & - & 0.469 & 0.600 & 0.576 \\
& Peru & 0.266 & 0.398 & 0.306 & - & 0.503 & 0.465 \\
& Surinam & 0.375 & 0.114 & 0.408 & 0.348 & - & 0.484 \\
\hline E. guineensis & Africa & 0.281 & 0.276 & 0.321 & 0.290 & 0.277 & - \\
\hline
\end{tabular}


The presence of specific alleles showed elsewhere (Barcelos et al., 2000), and specific fragments revealed here support the hypothesis of drift and recent bottleneck events experienced by these groups. This is explained by the low genetic diversity found in this study (Table 2 and Table 4).

The parameters of genetic diversity estimated using either RFLP or AFLP were in agreement as show in Table 2 and Table 4 . The structure revealed by cluster analysis using RFLP or AFLP data placed African species in an intermediate group between the American sources. The African species made up an isolated group when using AFLP data. This result can be attributed to the capacity of the AFLP technique to reveal a different polymorphism by screening different parts of the genome (Marsan et al., 1998).

\section{Intra specific genetic divergence}

In E. oleifera, the distinction of four groups Brazil, Peru, Central America Group (north of Colombia, Panama, Costa Rica and Nicaragua) and Guyana (French Guyana and Surinam), coincident with their geographical origins - indicates that the genetic isolation was due to the history of variable
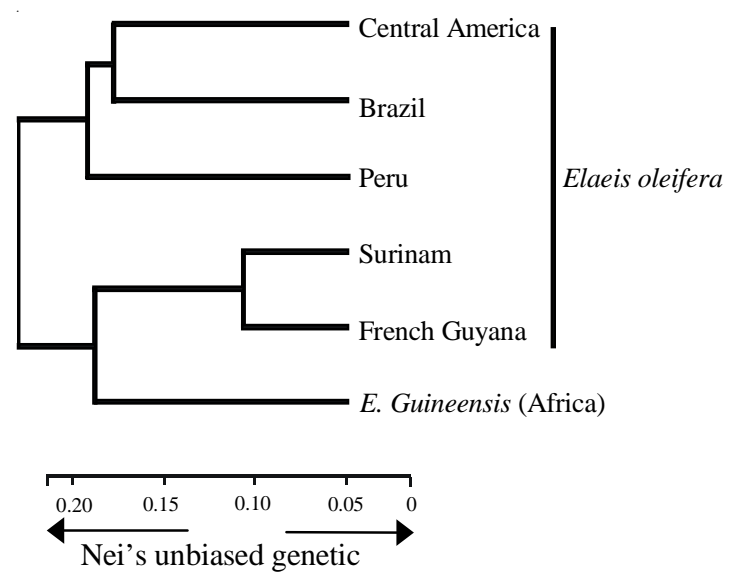

Figure 2. Genetic relationships between E. guineensis and five geographical groups of E. oleifera accessions. Dendrogram based on Nei (1978) unbiased genetic distance calculated for RFLP band frequencies per group or species. RFLP bands were scored for presence or absence in 241 E. oleifera and 38 E. guineensis accessions. and discontinuous distribution within the American continent. The genetic diversity within each of the 32 studied Brazilian populations was higher than that in the non-Brazilian geographical groups (Barcelos et al., 2000). This suggests a substantial genetic drift and bottleneck effect among the American groups other than the Brazilian.

The continuous distribution of E. guineensis on the African continent, without geographical barrier to gene flow and the great human influence on material dispersion for this species (Zeven, 1964) may explain the low level of genetic structuring observed in the group representing all African origins (Figures 3 and 5). The genetic organization splitted into three groups: La Mé/Côte d'Ivoire, YangambiSibiti/Zaire and Deli (plus other African origins), as revealed in this study, is in agreement with the breeding populations structure based on agromorphological characterizations (Gascon, 1989). This leads to the assumption that, despite the relatively small sample (38), it represents the genetic diversity of this species.

The Reciprocal Recurrent Selection breeding method adopted for oil palm divides the breeding material into two major groups: African, composed by La Mé and Yangambi-Sibiti origins; and Deli group, comprising some other African origins. This group structure was proposed by considering the

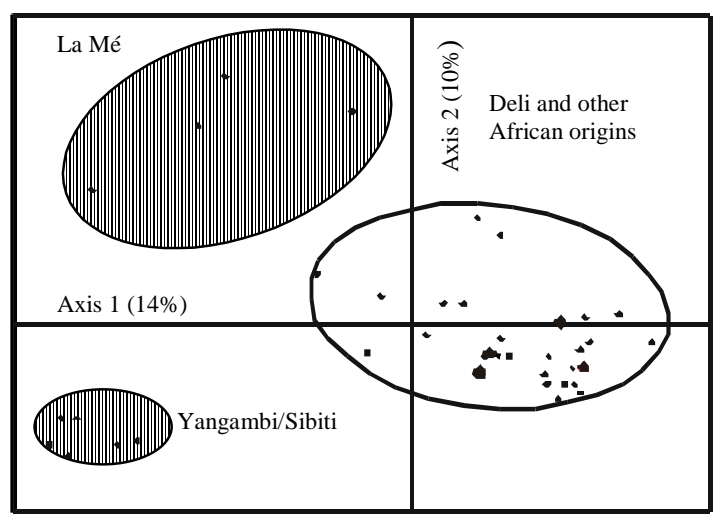

Figure 3. Factorial Analysis of Correspondences on 170 nuclear RFLP bands revealed by 37 cDNA probes over 38 E. guineensis African accessions. La Mé accessions are from Côte d'Ivoire and Yangambi/Sibiti from Congo/Zaire. First plane (Axes 1-2) represented $24 \%$ of total variability. 
Table 4. Genetic diversity parameters estimated by using 169 AFLP markers revealed by three primers/enzymes combinations over 44 accessions of E. oleifera and 22 accessions of E. guineensis.

\begin{tabular}{llccccc}
\hline Species & Group & Sample & Polymorphic & \multicolumn{2}{c}{ Number of fragments } & \multirow{2}{*}{ HNei $^{(1)}$} \\
\cline { 5 - 6 } & & size & loci $(\%)$ & Total & Specific & \\
\hline E. oleifera & Brazil & 28 & 56 & 79 & 24 & 0.178 \\
& French Guyana & 2 & 3 & 64 & 1 & 0.012 \\
& Central America & 10 & 12 & 72 & 3 & 0.050 \\
& Peru & 2 & 12 & 68 & 8 & 0.049 \\
& Surinam & 2 & 4 & 62 & 5 & 0.017 \\
\cline { 2 - 5 } & Total & 44 & 95 & 169 & 96 & 0.298 \\
\hline E. guineensis & Africa & 22 & 38 & 39 & 3 & 0.117 \\
\hline
\end{tabular}

${ }^{(1)}$ Nei's genetic diversity index - genetic diversity at intra group level (Nei, 1973).

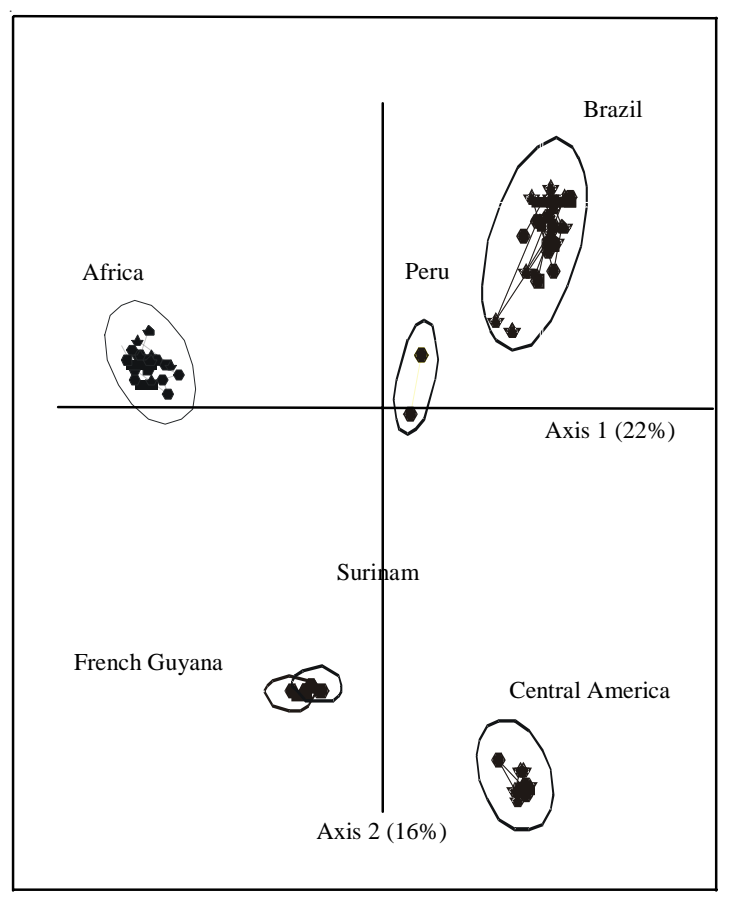

Figure 4. Factorial Analysis of Correspondences performed on 169 AFLP markers revealed by three pairs of enzyme/primers over 40 accessions of American E. oleifera and 21 accessions of African E. guineensis. First plane (Axes 1-2) represented 38\% of total variability.

complementarity of yield components characters revealed by quantitative genetic studies (Gascon, 1989). The FAC analysis (Figure 3) and AFLP data (Figure 5) reflect the genetic difference between these groups exploited by classical breeding results.

\section{Inter species genetic differentiation}

RFLP and AFLP analyses revealed gene diversity (Nei, 1973): $\mathrm{H}=0.225$ and $\mathrm{H}=0.298$ for E. oleifera, and $\mathrm{H}=0.135$ and $\mathrm{H}=0.117$ for $E$. guineensis. The values revealed by RFLP and AFLP techniques only for the Brazilian accessions were $\mathrm{H}=0.157$ and 0.178 respectively, within the same order of magnitude than those found for the African species. These values are equivalent to the results revealed by isoenzymes, which revealed $\mathrm{H}=0.310$ and $\mathrm{H}=0.410$ for the Brazilian and African origins respectively (Ghesquière et al., 1987).

In the present study, results of RFLP and AFLP as dominant markers analysis were concordant with the RFLP scored as co-dominant markers (Barcelos et al., 2000) and with isoenzymes (Ghesquière et al., 1987).

The genetic diversity relationship between the two Elaeis species revealed by AFLP analysis (Figure 5), is presented here as slightly different from the RFLP diversity structuring (Figure 2), by clustering the African species out of the American group. These results suggest that the genetic divergence between the two species, revealed by AFLP markers, is more important than the divergence detected by RFLP markers. The RFLP detected by using de cDNA probes normally reveal the DNA variations on the coding genes then a more conserved region, while the AFLP technique may assay different parts of the genome, being able to detect much more polymorphism by screening in all DNA, including the repeated sequences rich regions (Hill et al., 1996; Powell et al., 1996; Sharma et al., 1996; Marsan et al., 1998).

Despite the geographical distance between the natural distribution of E. oleifera and E. guineensis, 
the number of RFLP and AFLP common fragments, the number of common alleles as revealed elsewhere (Barcelos et al., 2000), and the absence of a genetic reproductive barrier between both species, it can be concluded that these two species present a relatively small genetic divergence, suggesting that the gene flow interruption between them is relatively recent, allowing also for some non exclusive hypotheses: a) The genus Elaeis, with an origin in East Gondwana, as considered for various other palm genes (Moore \& Uhl, 1982) was probably derived from the present Upper Amazonian region in South America. Separated by continent drift, the genus diverged into two species, E. guineensis in Africa and E. oleifera in South America. The small genetic divergence between the two species, despite being separated such a long time, could result from a low evolution in palm genome. The evolution of chloroplast genome in palms is considered to be eight times slower than in annual plants (Wilson et al., 1990), and permits the assumption of the same pattern for nuclear palm genome evolution. The intra American group separation could be recent and strongly marked by probably various bottleneck episodes during the

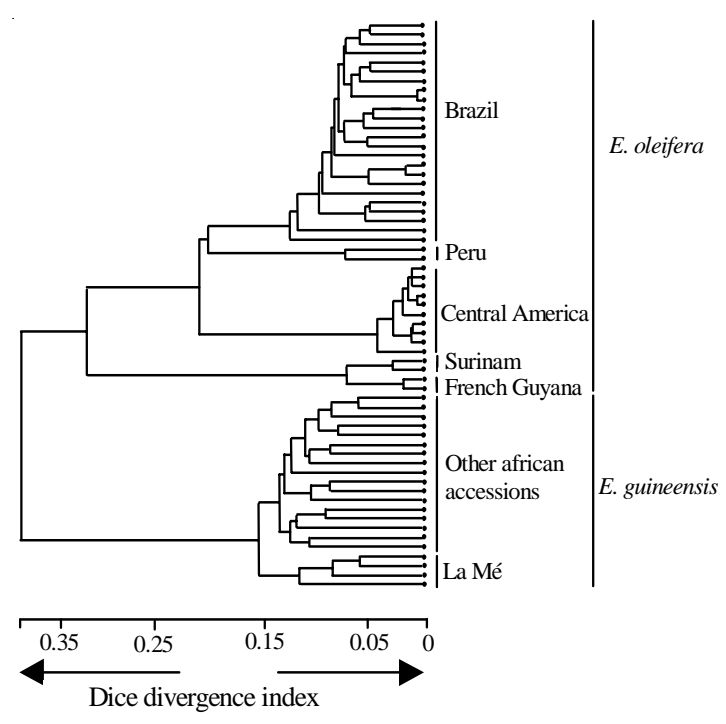

Figure 5. Relationships between 40 Elaeis oleifera and 21 E. guineensis accessions. UPGMA dendrogram based on Dice divergence index calculated with 169 AFLP markers revealed by three enzyme/primer combinations. many glaciation events. b) E. oleifera was originated and dispersed from Upper Amazonian region, to establish all the other groups (French Guyana, Surinam and Central America), including the E. guineensis in the African continent. Those were independent events and the inexistence of gene flow between the groups due to geographical barriers, resulted in the important genetic drift, and the present divergence between them. The differentiation between African species and Brazilian origins are equivalent or smaller than the divergence between the African and the French Guyana/Surinam group. The isolation among the American groups was maintained by more recent paleoclimatological events, like glacial periods. When and how E. oleifera arrived in the African continent remains unclear under this scenario. According to palynological studies, E. guineensis has been in Africa for 50 million years, since the Upper Miocene (Zeven, 1964). This suggests that gene flow was maintained between the two continents long after their separation. How to explain seed transport through Atlantic Ocean without human action remains unclear, considering the impossibility of seeds floating for a such long distance.

\section{Conclusions}

1. The use of RFLP and AFLP molecular markers to evaluate the genetic diversity on both oil palm species (E. oleifera and E. guineensis) gives results highly concordant.

2. AFLPs are able to detect equivalent genetic polymorphism and more divergence between the two species than RFLP markers; the number of polymorphic markers obtained with only three AFLP primers is of the same order of magnitude as the number obtained with a much more laborious 37 RFLP assays, indicating that AFLP is a powerful technique, able to provide a feasible and fast way to characterize large collection of genetic resources.

3 . The E. oleifera genetic diversity level and structure point to a higher diversity compared to the analyzed accessions of the African species E. guineensis.

4. In terms of ancestry of the two species, the relatively low level of genetic divergence detected between them suggests a common origin and a conserved genome for the genus. 


\section{References}

AMBLARD, P.; NOIRET, J. M.; KOUAMÉ, B.; POTIER, F.; ADON, B. Performances comparées des hybrides interspécifiques et du matériel commercial E. guineensis. Oléagineux, Corps Gras et Lipides, Montpellier, v. 2, p. 335-340, 1995.

BARCELOS, E.; AMBLARD, P.; BERTHAUD, J.; SEGUIM, M. The genetic diversity of the American oil palm, Elaeis oleifera (Kunth) Cortés revealed by nuclear RFLP markers. In: INTERNATIONAL SYMPOSIUM ON OIL PALM GENETIC RESOURCES AND UTILIZATION, 2000, Kuala Lumpur. Proceedings... Kuala Lumpur: The Malaysian Palm Oil Board, 2000. p. 173-192.

BENZECRI, J. P. L'analyse des données 2: 1'analyse des correspondances. Paris: Dunod, 1973. 620 p.

BESSE, P.; SEGUIN, M.; LEBRUN, P.; CHEVALIER, M. H.; NICOLAS, D. Genetic diversity among wild and cultivated populations of Hevea brasiliensis assessed by nuclear RFLP analysis. Theoretical and Applied Genetics, Berlin, v. 88, p. 199-207, 1994.

GASCON, J. P. Amélioration du palmier à huile. Actualités Botaniques, Chatenay-Malabry, v. 136 , n. $3 / 4$, p. 236271, 1989.

GHESQUIÈRE, M.; BARCELOS, E.; SANTOS, M. M.; AMBLARD, P. Polymorphisme enzymatique chez Elaeis oleifera H. B. K. Cortés (Elaeis melanococca): analyse des populations du bassin amazonien. Oléagineux, Montpellier, v. 42, p. 143-153, 1987.

HARDON, J. J.; TAN, G. Y. Interspecific hybrids in the Elaeis. I. Crossability, cytogenetics and fertility of $\mathrm{F}_{1}$ hybrids of E. guineensis x E. oleifera. Euphytica, Dordrecht, v. 18, p. 372-379, 1969.

HARTLEY, C. W. S. The oil palm. Essex: Longman, 1988. $761 \mathrm{p}$.

HILL, M. W. H.; ZABEAU, M.; VOS, P.; KESSELI, R. PCR-based fingerprinting using AFLPs as a tool for studying genetic relationships in Lactuca spp. Theoretical and Applied Genetics, Berlin, v. 93, p. 1202-1210, 1996.

JACK, P. L.; DIMITRIJEVIC, T. A. F.; MAYES, S. Assessment of nuclear, mitochondrial and chloroplast RFLP markers in oil palm (Elaeis guineensis Jacq.). Theoretical and Applied Genetics, Berlin, v. 90, n. $643-$ 649, 1995.
KARP, A.; EDWARDS, K. J. Molecular techniques in the analysis of the extent and distribution of genetic diversity. In: AYAD, T. H. W. G.; JARADAT, A.; RAO, V. R. (Ed.). Molecular genetic techniques for plant genetic resources. Rome: International Plant Genetic Resources Institute, 1997. v. 1, p. 11-22.

LANAUD, C.; LEBOT, V. Molecular techniques for increasing use of genetic resources. In: AYAD, T. H. W. G.; JARADAT, A.; RAO, V. R. (Ed.). Molecular genetic techniques for plant genetic resources. Rome: International Plant Genetic Resources Institute, 1997. v. 1, p. 92-97.

LEBEAUX, M. O. ADDAD: guide de l'utilisateur. Paris: Association pour le Développement et la Diffusion de l'Analyse des Données, 1985. 220 p.

LEBRUN, P.; BAUDOUIN, L.; SEGUIN, M.; N'CHO, Y. P.; BOURDEIX, R. Study on the genetic diversity of coconut palm by means of RFLP. Oléagineux, Corps Gras et Lipides, Montpellier, v. 2, p. 418-421, 1995.

LERCETEAU, E.; ROBERT, T.; PETIARD, V.; CROUZILLAT, D. Evaluation of the extent of genetic variability among Theobroma cacao accessions using RAPD adn RFLP markers. Theoretical and Applied Genetics, Berlin, v. 95, n. 1/2, p. 10-19, 1997.

LUO, H.; BOUTRY, M. Phylogenetic relationships with Hevea brasiliensis as deduced from a polymorphic mitochondrial. Theoretical and Applied Genetics, Berlin, v. 91, p. 876-884, 1995.

MARSAN, P. A.; CASTIGLIONE, P.; FUSARI, F.; KUIPER, M.; MOTTO, M. Genetic diversity and its relationship to hybrid performance in maize as revealed by RFLP and AFLP markers. Theoretical and Applied Genetics, Berlin, v. 96, p. 219-227, 1998.

MOORE, H. E.; UHL, N. W. Major trends of evolution of palms. Botanical Review, New York, v. 48, p. 1-69, 1982.

NEI, M. Analysis of gene diversity in subdivided populations. Proceedings of the National Academy of Sciences of the United States of America, Washington, v. 70, p. 3321-3323, 1973.

NEI, M. Estimation of average heterozygosity and genetic distance from a small number of individuals. Genetics, v. 89 , p. 583-590, 1978.

NEI, M.; LI, W. H. Mathematical model for studying genetic variation in terms of restriction endonucleases. 
Proceedings of the National Academy of Sciences of the United States of America, Washington, v. 76, p. 52695273, 1979.

N'GORAN, J. A. K.; LAURENT, V.; RISTERUCCI, A. M.; LANAUD, C. Comparative genetic diversity studies of Theobroma cacao L. using RFLP and RAPD markers. Heredity, Oxford, v. 73, p. 589-597, 1994.

PAUL, S.; WACHIRA, F. N.; POWELL, W.; WAUGH, R. Diversity and genetic differentiation among populations of Indian and Kenyan tea (Camellia sinensis (L.) Kuntze) revealed by AFLP markers. Theoretical and Applied Genetics, Berlin, v. 94, p. 255-263, 1997.

POWELL, W.; MORGANTE, M.; ANDRE, C.; HANAFEY, M.; VOGEL, J. The comparison of RFLP, RAPD, AFLP and SSR (microsatellite) markers for germplasm analysis. Molecular Breeding, Dordrecht, v. 2, p. 225-238, 1996.

RAJANAIDU, N. PORIM oil palm genebank: collection, evaluation, utilization and conservation of oil palm resources. Selangor: Palm Oil Research Institute of Malaysia, 1994. 19 p.

SHARMA, S. K.; KNOX, M. R.; ELLIS, T. H. N. AFPL analysis of diversity and phylogeny of lens and its comparison with RAPD analysis. Theoretical and Applied Genetics, Berlin, v. 93, p. 751-758, 1996.

SIMMONDS, N. W. Introgression and incorporation: strategies for the use of crop genetic resources. Biological Review, New York, v. 68, p. 539-562, 1993.

VOS, P.; HOGERS, R.; BLEEKER, M.; REIJANS, M.; LEE, T. van de. AFLP: a new technique for DNA fingerprinting. Nucleic Acids Research, Oxford, v. 23, p. 4407-4414, 1995.

WILSON, M.; GAUT, A. B.; GLEGG, M. T. Chloroplast DNA evolves slowly in the palm family (Arecaceae) Molecular Biology and Evolution, Canberra, v. 7, p. 303314, 1990.

ZEVEN, A. C. The origin of the oil palm (Elaeis guineensis Jacq.). Grana Palynologica, Stockolm, v. 5, p. 121-123, 1964. 